\title{
The Current Situation and Development of English Education in Chinese Colleges and Universities
}

Ting Tan

Hunan University of Technology, lecturer, Zhuzhou, Hunan, China.

Email: 372233163@qq.com

\begin{abstract}
The in-depth implementation of the reform of higher education has made educators pay more attention to the innovation of teaching concepts, hoping to achieve the purpose of promoting the high quality of students' learning effectiveness in the process of establishing new classroom teaching activities. But the reality is that many teachers still have to solve many difficulties in classroom teaching activities in order to ensure the orderly development of teaching activities. This article starts with the factors that hinder the orderly development of English teaching activities in colleges and universities, and finds specific solutions, hoping to provide references for other educators.
\end{abstract}

Keywords: Status and Development; Higher Education; Teaching Status; English Class

The rapid development of the times has also injected new vitality into my country's education field. With the increasingly prominent international status of English, how to ensure the smooth progress of English education has become a problem that needs to be solved by teachers. As a key base for cultivating highly-skilled talents, an institution of higher learning shoulders the important responsibility mission of delivering talents to the society. This requires teachers to carry out in-depth research on the current status of education, and combined with the learning situation of class students, to improve the teaching plan accordingly, so as to promote advanced English in the process of constructing high-efficiency English classroom teaching activities The long-term development of education in the future.

\section{Factors that hinder the orderly development of English teaching activities in colleges and universities}

\subsection{Indoctrination teaching mode still exists}

Although college students already have strong self-learning ability and inquiry ability, they can ensure the efficient completion of learning tasks under the guidance of teachers. However, many teachers still use the inculcating teaching mode for English teaching activities. In this English classroom that ignores students' thinking ability and enthusiasm for learning, students not only have difficulty in mobilizing their enthusiasm to participate in knowledge learning through the extension of thinking consciousness, but also can't feel the fun of learning English knowledge in the process of passively receiving knowledge This will seriously affect the orderly development of classroom teaching activities. At the same time, the indoctrination teaching model puts too much emphasis on the central position of teachers in the classroom, resulting in the overall teaching progress under the control of teachers, it is difficult to coordinate with the students' ability to accept knowledge. Under such a teaching environment that severely inhibits the student's learning subjectivity, not only the student's learning efficiency is seriously reduced, but also the teaching effectiveness is difficult to achieve an effective increase.

\subsection{Serious lack of communication between teachers and students}

Copyright (C) 2020 Ting Tan

doi: $10.18282 /$ le.v9i5.1241

This is an open-access article distributed under the terms of the Creative Commons Attribution Non-Commercial License

(http://creativecommons.org/licenses/by-nc/4.0/), which permits unrestricted non-commercial use, distribution, and reproduction in any medium, provided the original work is properly cited. 
University study life is easier than busy high school life, so students' self-learning ability and learning initiative are more investigated. Many students communicate with teachers only in short classroom teaching activities. Therefore, in the reality of lack of effective communication between teachers and students, it is difficult for teachers to master the overall learning needs of class students, and the designed teaching content is also Often deviates from students' interest in learning. Therefore, in this teaching situation, the communication between teachers and students becomes dispensable. Teachers cannot improve the teaching content according to the overall learning situation of students, and students cannot close the distance with teachers. In a vicious circle, it is always difficult to effectively improve the quality of teaching.

\section{Specific strategies for the orderly development of English teaching activities in colleges and universities}

\subsection{Attach importance to the introduction of new teaching models}

As an international language, English not only keeps improving its international status, but also the society needs more and more high-quality English talents. In order to enable students to improve their English literacy, communicative ability, practical ability and language application ability through the participation of English classrooms, teachers should break through the constraints of the old teaching model and actively look for teaching methods that can mobilize students' initiative in learning and learning. In the process of student learning quality, it promotes highly effective classroom teaching activities. Therefore, teachers should be aware of the importance of respecting the main position of students in the classroom when conducting teaching activities, and in combination with the specific teaching content, the teaching methods such as problem guidance, flipped classroom teaching mode, group cooperative learning mode and other teaching methods should be actively introduced into the English classroom in. In a more diverse learning environment, students not only can more easily mobilize their enthusiasm for participating in classroom knowledge learning, but they can also realize the significance of actively participating in classroom knowledge learning under the guidance of teachers. And students who break through the passive learning model can actively find a learning method that is more in line with their own learning needs through the extension of their thinking consciousness and the application of inquiry ability when participating in the English classroom, so as to ensure the rapid improvement of learning efficiency and achieve a comprehensive The purpose of development.

\subsection{Build a close communication platform between teachers and students}

In order to ensure the orderly conduct of English teaching classes, teachers need to realize the importance of close communication with students. Therefore, teachers can make full use of the Internet platform to establish channels for close communication with students, so as to better understand the learning requirements of students and ensure that the content of the lectures can be better improved in the elaborate design of teachers. For example, through the introduction of micro-class video, teachers can upload the key teaching content to the cloud disk in the form of video, and give students account and password to ask them to complete self-learning tasks after downloading before class. At the same time, students also need to upload the preview experience and questions to the cloud disk in the form of documents, so that the teacher can improve the teaching plan by collecting the students' learning situation. In this process of close communication between teachers and students, not only can teachers ensure the smooth development of classroom teaching activities according to students' learning requirements, but students can also feedback to teachers in time when they encounter problems, and quickly with the help of teachers Complete the learning of knowledge.

\section{Conclusion}

Social changes and the development of the times have injected fresh blood into the field of education. Therefore, teachers of colleges and universities need to closely follow the tide of the development of the times when carrying out English education, and constantly break the constraints of old educational concepts, so that teaching activities can meet the learning needs of students while making their application ability, inquiry ability and learning Quality can be effectively improved. This can not only ensure the rise of the effectiveness of English education, but also promote the 
development of students in an all-round way, so that they can get better development.

\section{References}

1. Cao Xiuping. Research on the Current Situation and Problems of Cultural Confidence Training in English Education of Local Undergraduate Colleges__ Taking Hubei University of Arts and Sciences as an Example[J]. Journal of Hubei University of Arts and Sciences, 2020,41(03):66-71.

2. Guo Rui. Research on the Reform of Talent Cultivation Model of English Education in Applied Universities under the New National Standard [C]. Organizing Committee of the International Forum on Northeast Asian Linguistics, Literature and Teaching. Northeast Asian Foreign Language Forum (2019 NO.4 Total Issue 14) ). Organizing Committee of the International Forum on Linguistics, Literature and Teaching in Northeast Asia: Shenyang Dongshi Ruipu Education Technology Co., Ltd., 2019: 81-90.

3. Li Cong, Wang Ning. National cultural safety-oriented reform of college English education_Comment on "Education Safety Theory: Based on the Perspective of National Cultural Safety"[J]. China Safety Production Science and Technology, 2019, 15(09): 190. 